\title{
To Age or Not to Age-Modern versus Traditional Concepts \\ Gilca $\mathbf{M}^{*}$ \\ Carol Davila University of Medicine and Pharmaceutics, Romania
}

\begin{abstract}
The modern oxidative hypothesis of ageing states that oxidative stress is a significant marker of senescence. This age related-oxidative stress is generated by a combination of increased free radicals production, decreased antioxidants levels and impaired repair of oxidative damages. Modern scientific anti-aging strategies delay the loss of physiological functions by modulating the activity of antioxidants and oxidants in the body. Various redox-dependent gerontomodulatory approaches include: (I) nutritional and pharmacological intervention by free radical scavengers (antioxidant therapy); (II) hormesis based interventions (caloric restriction, fasting, pro-oxidants). On the other hand, traditional Rasayana chikitsa (ayurvedic rejuvenation therapy) also provides certain dietary and therapeutic measures which are able to arrest process of ageing and can even rejuvenate whole functional dynamics of the body system. According to Ayurveda, reversal of ageing process is possible if Rasayana therapy is applied before a critical age (which depends upon the organ involved in sequential ageing process). Correlations between redox-dependent gerontomodulatory approaches and ayurvedic antiageing strategies (Rasayana chikitsa, preparatory procedures for Rasayana chikitsa) are presented and discussed in this paper. A literature search was conducted to collect data from studies on Rasayana drugs and fasting available up to November 2012 using PubMed and High wire.
\end{abstract}

Based on this review, it appears that Rasayana drugs have cytoprotective and antioxidant effects, while fasting therapy has a direct effect on the modulation of free radicals synthesis. Thus, this integrative approach including modern and traditional concepts can be a lead towards future rejuvenative therapy research in the management of ageing

Keywords: Ageing; Rasayana; Fasting; Antioxidant; Cytoprotection

\section{Introduction}

There is a strong scientific evidence that free radicals and the oxidative stress play an important role in ageing [1]. Hence, the modern anti-ageing strategies are oriented towards the modulation of the redox status of the body. Various redox-dependent gerontomodulatory approaches include: (I) nutritional and pharmacological intervention by free radical scavengers (antioxidant therapy); (II) hormesis based interventions (e.g. caloric restriction, intermittent fasting, mild prooxidative therapy, etc.)

Modern scientific anti-aging strategies do not claim to cure "senescence", but to delay the process of ageing. On the other hand, complete reversal of ageing process is possible according to Ayurveda, but only if anti-ageing therapy is applied before a critical age. This claim is still to be validated through scientific tools. Traditional antiageing strategies include: (1) Rasayana chikitsa (ayurvedic rejuvenation therapy) e.g. consisting of certain dietary and therapeutic measures like herbal preparations which are able to correct structural abnormalities of the dhatus (tissue) by a proper nutrition, and (2) preparatory procedures for Rasayana, which correct dosha disturbances and Agni (digestive fire). According to Ayurveda, there are three vital bioenergies called doshas (vata, pitta, kapha) which are derived from the five elements; the doshas are responsible for the physical and emotional tendencies in the mind and body, and along with the seven dhatus (tissues) and three malas (waste products) make up the human body.

Rasayana drugs are administered in a special way in order to get maximum benefits. From the standpoint of administration, there are two types of Rasayana: 1) kuțiprāveśika (rasayana therapy is administered by keeping the person in seclusion, inside of a special hut, called $k u t i$, that should have three chambers, one inside another (so that no direct contact with wind or sun may take place); kutiprāveśika is the most beneficial type of rasayana, and may be also called nonambulatory rasayana); 2) vātātapika (rasayana therapy is administered ambulatory, even if the person is exposed to the wind and the sun; vātātapika is less beneficial than kuțiprāveśika) (Charaka Samhita, Cikitsasthana, ch I:16-24) [2].

Kuțiprāveśika is believed to be "totally transforming the body", and therefore also termed as kayakalpa (kaya means body, and kalpa means proper, fit, transformation, change).

There are more anecdotal histories reporting the extraordinary effects of kayakalpa or kuțiprāveśika, e.g. the remarkable case of Shriman Tapasviji Maharaj, who underwent three times kayakalpa (first time at the age of 100 years), and who lived 185 years. His birth year was given as $1770 \mathrm{AD}$ and the year of his death is reported as 1955 $\mathrm{AD}$ [3]. Taking into account all these; we suggest that the concept of kuțiprāveśika or kayakalpa would be of interest to the new emerging approach of modern reparative and regenerative medicine.

Cytoprotective and antioxidant properties of Rasayana drugs and effects of fasting on redox status of the body, as well as correlations between modern and traditional anti-ageing strategies are mentioned in the present review.

A literature search was conducted to collect data from studies on Rasayana drugs and fasting using PubMed and Highwire. All the data collected was published in English and available up to November 2010, "antiageing", "antioxidant", "cytoprotective", "oxidative stress", "reactive oxygen species", "free radicals", "medicinal plant", "rasayana" and "ayurveda" were used as search terms. A supplemental manual search of the references in the identified articles and of different traditional or modern medical books was performed.

\section{The modern oxidative hypothesis of ageing versus the traditional Ayurvedic theory of ageing}

The modern oxidative hypothesis of ageing states that oxidative

*Corresponding author: Marilena Gilca, Carol Davila University of Medicine and Pharmaceutics, B-dul Eroilor Sanitari no.8, sector 5, 50471, Romania; E-mail: marilenagilca@gmail.com

Received May 23, 2013; Accepted July 04, 2013; Published July 06, 2013

Citation: Gilca Ma (2013) To Age or Not to Age-Modern versus Traditional Concepts. Altern Integ Med 2: 128. doi:10.4172/2327-5162.1000128

Copyright: (C) 2013 Gilca Ma. This is an open-access article distributed under the terms of the Creative Commons Attribution License, which permits unrestricted use, distribution, and reproduction in any medium, provided the original author and source are credited. 
stress is a significant marker of senescence [1,2]. This age relatedoxidative stress requires the presence of oxygen, an increased production of free radicals and a decreased antioxidant protection. We have found similarities between this oxidative triad and the "Fire Triangle" (Figure 1): oxygen symbolized by the Air component, increased free radicals production by the Ignition component and tissues with decreased antioxidants levels and impaired repair of oxidative damages by the Fuel component. Fire Triangle is a simple model used in the modern science of fire fighting for illustrating the ingredients necessary for most fires: oxygen, ignition and fuel. Without ignition the fire cannot begin: oxygen reacts with the fuel only if the reaction is initiated by an activating energy, in most cases heat, but also friction, electricity, radiation, pressure, all of them leading to a rise in temperature. The chemical reaction creates heat that causes more fuel to become available. Similarly, the lipid peroxidation of the fatty acids creates peroxyl radicals, which in turn generates more free radicals. Thus, an uninhibited chain reaction of "burning" the "fuel" (fatty acids) leads to the destruction of the cell membranes. The Fire stops when one or more of the ingredients is removed. Similarly, the lipid peroxidation stops if antioxidant protection is improved ("non-inflammable fuel") and free radical synthesis ("ignition") is controlled.

The traditional theory states that ageing also requires the presence of three factors: vata aggravation as Air component (vata itself is a combination of vayu or air as the predominant element and space or akasha as the secondary element), uncontrolled Agni as Ignition component and vulnerable dhatus (tissues) as Fuel component (Figure 2).

\section{लाभोपायो हि शस्तानां रसादीनां रसायनम्॥ २॥}

lābhopāyo hi śastānām rasādīnām rasāyanam | | 2 | |

According to Ashtanga Samgraha, the definition of Rasayana is "the method of obtaining the benefits of excellence of rasa (plasma) and other dhatus (tissues)" (Ashtanga Samgraha ch 49:2) [4,5].

Therefore rasayana addresses to the Fuel component of the triangle, the vulnerable dhatus (tissues). In other words, rasayana improves the quality of the Fuel, understanding by this that rasayana decreases the availability of the Fuel to the Fire. But how the ayurvedic treatment controls the other two components of the Fire Triangle? Another sloka from Ashtanga Samgraha states that: "Rasayana administered without

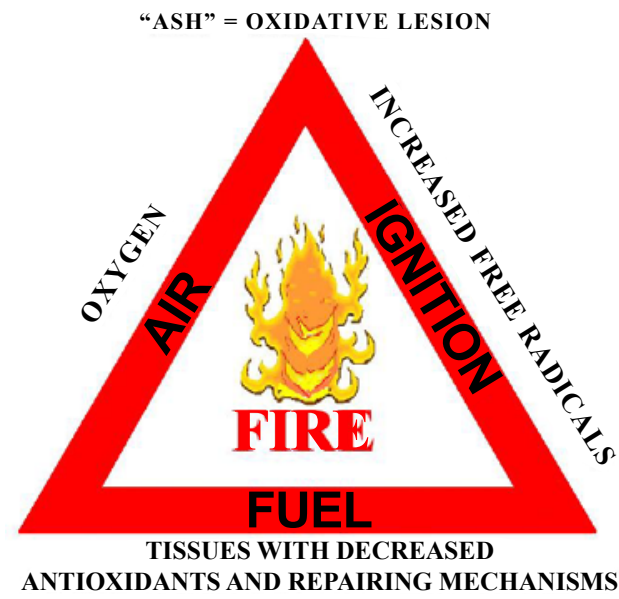

Figure 1: The modern theory of ageing.

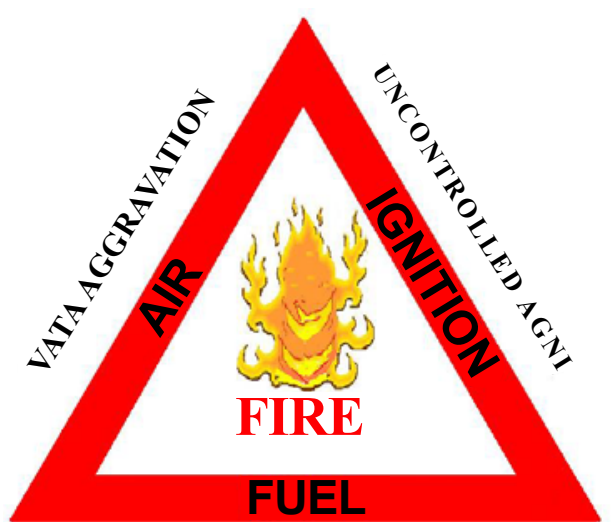

VULNERABLE DHATUS

Figure 2: The traditional theory of ageing.

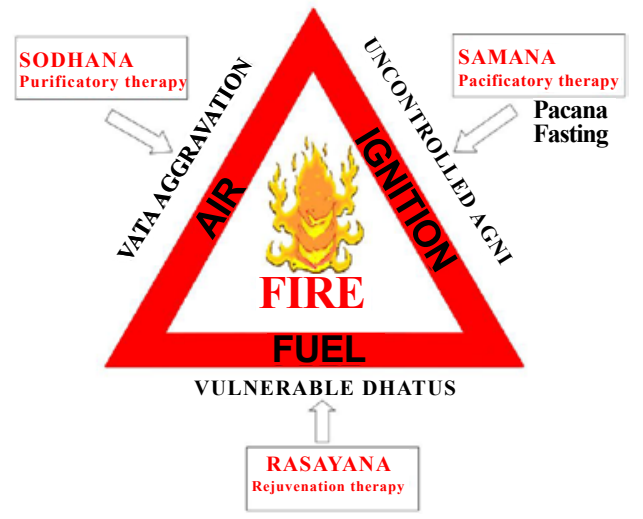

Figure 3: Control of the three components (Fuel, Air, and Ignition) of Fire Triangle by ayurvedic therapeutic measures.

purifying the body does not help, just like a dirty cloth does not shine by coloring." (Ashtanga Samgraha ch 49:4) [5].

\section{अविशुद्धे शरीरे हि युक्तो रासायनो विधिः।}

aviśuddhe śarīre hi yukto rāsāyano vidhị̣ |

\section{न भाति मलसंसृष्टे वस्त्रे राग इवार्पितः॥४॥ \\ na bhāti malasamsự̦țe vastre rāga ivārpitah | | 4 | |}

Hence, the necessity of the preparatory therapies for Rasayana, which includes, 1 . sodhana or purificatory therapy, addressing to the Air component (e.g. basti or anorectal administration of medicated oils and decoction which eliminate aggravated Vata from the colon, which is the main site of Vata accumulation in the body) and shamana or pacificatory therapy like pacana (digestive stimulants e.g. ginger and other spices in general) and fasting, which address the Ignition component by helping to control Agni (Figure 3).

Integrative hypothesis: Rasayana drugs have cytoprotective and antioxidant properties

The first integrative hypothesis is that a Rasayana drug should have cytoprotective and antioxidant properties, as its expression to improve 


\begin{tabular}{|c|c|c|c|}
\hline Drug & $\begin{array}{l}\text { Cytoprotection } \\
\text { (organ-toxic agent/stress/disease) }\end{array}$ & Antioxidant defense & References \\
\hline \multicolumn{4}{|l|}{ Single herbs } \\
\hline Amalaki (Emblica officinalis) & $\begin{array}{l}\text { Liver-reduced focal necrosis induced by } \mathrm{CCl}_{4}(\mathrm{~A}) \\
\text { Pancreas-protection against acute pancreatitis }(\mathrm{A} \\
\text { Stomach-reduced gastric mucosal injury induce by } \\
\text { indomethacin and necrotizing agents (A) }\end{array}$ & $\begin{array}{l}\text { Plasma-increased plasma antioxidant power in uremic } \\
\text { patients }(\mathrm{H})\end{array}$ & {$[7-10]$} \\
\hline $\begin{array}{l}\text { Ashwagandha } \\
\text { (Withania somnifera) }\end{array}$ & $\begin{array}{l}\text { Sperm-improves semen quality in infertile men }(\mathrm{H}) \\
\text { Stomach-adaptogenic activity against chronic stress (A) } \\
\text { Immune system-adaptogenic activity against chronic } \\
\text { stress (A) }\end{array}$ & $\begin{array}{l}\text { Nervous system-reduced oxidative damage in Parkinson's } \\
\text { disease model }(A) \\
\text { Seminal plasma-regulates oxidative stress in infertile men }(H)\end{array}$ & {$[11-13]$} \\
\hline Vacha (Acorus calamus) & $\begin{array}{l}\text { Nervous system- prevention of acrylamide-induced } \\
\text { paralysis and changes in the striatal dopamine receptors } \\
\text { in the corpus striatum (A) } \\
\text { Kidneys- reduced nickel chloride-induced renal toxicity, } \\
\text { and cell proliferation response (A) }\end{array}$ & $\begin{array}{l}\text { Nervous system-improved levels of antioxidant enzymes, } \\
\text { glutathione, malondialdehyde in Parkinson's disease model, } \\
\text { acrylamide neurotoxicity model (A) } \\
\text { Kidney-reduced nickel chloride-induced renal lipid } \\
\text { peroxidation, } \mathrm{H}_{2} \mathrm{O}_{2} \text { generation (A) }\end{array}$ & {$[14-16]$} \\
\hline Brahmi (Centella asiatica) & $\begin{array}{l}\text { Stomach, duodenum-protection against ethanol-, aspirin-, } \\
\text { cold-restraint stress-and pyloric ligation induced gastric } \\
\text { ulcers by increaseing the mucosal cell glycoproteins and } \\
\text { decreaseing cell shedding }(\mathrm{A})\end{array}$ & $\begin{array}{l}\text { Nervous system-prevents the 1-methyl-4-phenyl-1,2,3,6- } \\
\text { tetrahydropyridine-induced increase of lipid hydroperoxides } \\
\text { and protein-carbonyl content in substantia nigra (A) }\end{array}$ & {$[17,18]$} \\
\hline $\begin{array}{l}\text { Shatavari } \\
\text { (Asparagus racemosus) }\end{array}$ & $\begin{array}{l}\text { Stomach, duodenum- increased lifespan oof the mucosal } \\
\text { cells in acute gastric ulcers induced by cold restraint } \\
\text { stress, pyloric ligation, aspirin plus pyloric ligation, and } \\
\text { duodenal ulcers induced by cysteamine. (A) }\end{array}$ & $\begin{array}{l}\text { Liver-elevation of hepatic antioxidant status in } \\
\text { hypercholesteremic conditions (A) }\end{array}$ & {$[19,20]$} \\
\hline Guduchi (Tinospora cordifolia) & $\begin{array}{l}\text { Liver-prevents Isoniazid-, Rifampicin- and Pyrazinamide- } \\
\text { induced hepatic injury (A) } \\
\text { Nervous system-attenuates oxidative stress mediated cell } \\
\text { injury during oxygen-glucose deprivation }(\mathrm{V})\end{array}$ & $\begin{array}{l}\text { Lung, kidney, forestomach, brain- modulatory effect on } \\
\text { activities of antioxidant enzymes (A) }\end{array}$ & [21-23] \\
\hline $\begin{array}{l}\text { Vridha daraka } \\
\text { (Argureia speciosa) }\end{array}$ & Liver-prevents hepatic injuries (A) & Liver-increased antioxidant protection (A) & [24] \\
\hline \multicolumn{4}{|l|}{ Multiple herb formulations } \\
\hline Brahma rasayana & $\begin{array}{l}\text { Bone marrow-rapid rise in lymphocytes and neutrophils in } \\
\text { cancer patients undergoing radio and chemotherapy who } \\
\text { have developed leukopenia, neutropenia and lymphopenia } \\
\text { (H) }\end{array}$ & $\begin{array}{l}\text { Erythrocyte, plasma, liver (A)-decreased serum and liver } \\
\text { lipid peroxidation, increase in enzymatic and non-enzymatic } \\
\text { antioxidants in blood of heat stressed chickens } \\
\text { Plasma }(\mathrm{H}) \text {-decreased serum lipid peroxidation in cancer } \\
\text { pacients undergoing radio and chemotherapy }\end{array}$ & {$[25,26]$} \\
\hline Triphala & $\begin{array}{l}\text { Bone marrow, stomach, intestines- protection against } \\
\text { both gastrointestinal and hemopoetic death induced by } \\
\text { radiation }(A) \text {, restoration of the depleted protein level in } \\
\text { brush border membrane of intestine, and phospholipid } \\
\text { content in methotrexate-induced intestinal injury }(A)\end{array}$ & $\begin{array}{l}\text { Intestines-decreased the myeloperoxidase and xanthine } \\
\text { oxidase level in intestinal mucosa of methotrexate-treated rats } \\
\text { (A) }\end{array}$ & {$[27,28]$} \\
\hline Maharishi Amrit Kalash & $\begin{array}{l}\text { Nervous system-restoration of dark neurons population in } \\
\text { the ageing cerebellum }(A)\end{array}$ & $\begin{array}{l}\text { Cerebelum } \\
\text { (purkinje neurons)-reduced lipid peroxidation with ageing } \\
\text { process }(A)\end{array}$ & [29] \\
\hline Geriforte & $\begin{array}{l}\text { Bone marrow, stomach, intestines-protection against the } \\
\text { gastrointestinal death and bone marrow deaths induced } \\
\text { by radiation }(A) \\
\text { Lymphocytes-inhibition of the lymphocyte proliferation and } \\
\text { DNA fragmentation induced by tert-butylhydroperoxide }(V) \\
\text { Erythrocyte protection-increased membrane stability and } \\
\text { reduced cytotoxicity induced by azo-bis 2-amidinopropane } \\
\text { dihydrochloride }(H)\end{array}$ & $\begin{array}{l}\text { Lymphocytes-inhibition of the oxidative process induced by } \\
\text { tert-butylhydroperoxide }(\mathrm{V}) \\
\text { Liver, lung-selectively increased antioxidant enzyme activity } \\
\text { (A) } \\
\text { Erythrocyte-increased catalase activity }(\mathrm{H})\end{array}$ & [30-33] \\
\hline
\end{tabular}

(Legend: H-human study; A-animal study; V-in vitro study)

Table 1: Cytoprotective and antioxidant properties of different Rasayana drugs.

directly the quality of the Fuel (tissue protective mechanisms). This does not exclude indirect effects on the other two components of the Triangle, but these would be secondary to its primary action which is the cytoprotection and improvement of the antioxidant status of the cells. Sarangadhara (1300AD) describes aging in terms of sequential loss of certain biological qualities specific to different decades of life, and suggests various Rasayana remedies which could compensate these biolosses (e.g. Triphala administered during the $6^{\text {th }}$ decade of life prevents the loss of vision; ashwagandha administered during the $7^{\text {th }}$ decade of life prevents the loss of virility, etc.) [6]. A literature search confirmed that single medicinal plant or multiherbal formulations traditionally recognized as Rasayana activate different cytoprotective mechanisms and increase the cellular antioxidant defense (Table 1).

\section{Integrative hypothesis: Shamana therapy (e.g. fasting) can influence the free radical synthesis}

The second hypothesis is that a shamana procedure (e.g. fasting) addressing to the Ignition component of the Fire Triangle, should be able to influence the free radical synthesis. Free radicals have many Agni-like properties (Table 2). Although free radicals are predominantly implicated in causing cell damage, they also play major physiological roles (e.g. intracellular signalling, apoptosis regulation, antibacterial activity, etc.). They possess a dual quality since they can be either harmful or beneficial to living systems. The Janus face of free radicals as protective or toxic molecules is due to several factors, including their concentration: beneficial effects of free radicals occur at low/moderate 
Free radicals and other oxidant agents (e.g. $\mathrm{H}_{2} \mathrm{O}_{2}$ )

Light (Agni has two associated Biochemiluminescence (luminescence observed properties of heat and light). during the synthesis of free radicals in biological systems) [38]

Protection against diseases, Antimicrobial effects [39]

against toxins $\quad$ Apoptosis inductors [40] Stimulates cytokine synthesis [41]

Builds up the dhatus $\quad$ Insulin-like effects of hydrogen peroxide $\mathrm{H}_{2} \mathrm{O}_{2}$ mimics insulin action on glucose transport, glucose incorporation into glycogen, hexose mono-phosphate shunt pathway, lipid synthesis, and insulin receptor tyrosine kinase and pyruvate dehydrogenase activities) [42]

Table 2: Agni-like properties of free radicals

concentrations, while a deleterious process is initiated only when an overproduction of reactive species takes place [34-37].

A search of the literature identified several studies which showed the capacity of fasting to modulate free radical synthesis. A significant decrease in the mitochondrial generation of reactive oxygen species (ROS) was observed when mice were maintained on intermittent fasting that was initiated in middle age mice through a 4 month period. This alternate fasting also reduced significantly the incidence of lymphoma ( $0 \%$ versus $33 \%$ for controls) in aged mice, suggesting a possible role of fasting in preventing age-related diseases [43]. It was also suggested that a low rate of mitochondrial ROS generation extends lifespan both in caloric-restricted animals by determining the rate of oxidative attack and accumulation of somatic mutations in mitochondrial DNA [44].

One human clinical study showed that a short term fasting (80 hours) has induced a "spontaneous respiratory burst" of resting leukocytes, increasing the basal chemiluminescence (a potential biomarker of Agni) of these cells. In contrast with its effect on the resting leukocytes, fasting has decreased the stimulatory index of the prestimulated leukocytes or the "light production" of the "fighting cells" (possibly signifying a decrease of an excited Agni, such as that present in inflammatory conditions). This finding suggests that fasting may act as a gentle oxidative stress, which prestimulates the cells and, "train" them for a future real stress, having a possible adaptogen effect [45]. In conclusion, the global effect of fasting on Agni is a normalizing one: it may increase the Agni which is too low, and decrease the Agni which is too high.

Caloric restriction and intermitent fasting are already well documented hormetic methods of life-prolonging which increases efficiency of oxidative damages repair, enhances the antioxidant defence, and tonifies the imune system [46]. Hormesis based interventions represent a recent approach which use the repeated exposure to mild stress as a way to stimulate the maintenance and repair systems. Stresses that have been reported to improve lifespan or prevent age-related diseases are: caloric restriction, intermittent fasting, pro-oxidants, heavy metals, heat shock, irradiation (UV-, gamma-, and X-rays), exercise [47-50]. The antiageing effect of hormesis are accomplished by a complex network controlled by several genes called vitagenes and which includes the heat shock protein (HSP) pathway [51]. Among the heat shock proteins, heme oxygenase (HO) and HSP 70 are known for their capacity to reduce oxidative and nitrosative stress. Neurons respond to dietary restriction by upregulating the expression of proteins involved in the regulation of mitochondrial oxidative phosphorylation, e.g. uncoupling protein 4 (UCP4). UCP Uncoupling proteins (UCPs) are mitochondrial inner membrane proteins implicated in the regulation of cellular energy metabolism and oxygen consumption rate. The UCP4mediated shift in energy metabolism reduces reactive oxygen species
(ROS) production and increases the resistance of neurons to oxidative and mitochondrial stress [52].

\section{Integrative hypothesis: Rasayana drugs and shamana therapy reduce the oxidative damage}

A Rasayana drug and shamana therapy (fasting) may reduce the biomarkers of oxidative damage (the "ash"), as an expression of their capacity to enhance the cellular antioxidant protection and to decrease the ROS synthesis. Several studies showed the beneficial effects of fasting on the biomarkers of oxidative damage. A short-term fasting (average 7.2, range: 3-11 days) reduced the urinary malondialdehyde (MDA), but did not reduce the biomarkers of oxidative DNA damage among 52 healthy female volunteers (mean age 28, range 15-48 years old) participating in a program in South Korea [53]. Our team has also showed that a short-term fasting ( 80 hours) induced a decrease in total blood MDA, but not plasma MDA in 25 healthy volunteers (unpublished results). Two animal studies using male rats showed that an alternate-day fasting, as well as a caloric restriction (a $40 \%$ reduced calorie intake), prevented the age-related oxidative damage and fibrosis in the heart and aorta in terms of 4-hydroxynonenal (HNE)-protein adducts, malondialdehyde (MDA)-protein adducts and collagen content $[54,55]$. These data support the hypothesis that this kind of dietary restriction protects against age-related fibrosis, at least in part by reducing the accumulation of lipid peroxidation-derived aldehydes (Table 3) able to sustain a fibrotic process during ageing. Although, alternate day fasting may confer greater stress resistance than daily CR of $30 \%$ or $40 \%$ to oxidative damage [56].

The lipid peroxidation- derived aldehydes (HNE and MDA) have several Ama-like properties, and may be considered as biomarkers of ama accumulation in the body. For instance, Ama is picchila (sticky) and guru (heavy), similarly with MDA which "sticks" (reacts) to the proteins generating Schiff-type compounds which are "heavier" (have a higher molecular weight).

MDA is a product of incomplete polyunsaturated fatty acids (PUFA) oxidation similarly with $a m a$, which is defined as a product of incomplete digestion of nutrients. Ama becomes visha or toxin after being absorbed from the digestive tract into the circulation. Ama sticks to the tissues producing structural abnormalities and in the end, different diseases (Figure 4).

These results show that a well conducted fasting procedure may be a modality of "turning poison into nectar" by its capacity to decrease different lipid peroxidation products with ama-like properties. Further long term clinical studies are needed to prove the therapeutic potential of fasting.

\section{Conclusions}

The studies presented in this review suggest that Rasayana therapy and fasting may be included under redox-dependent gerontomodulatory

\section{Ama} Lipid-peroxidation aldehydes

Products of immature digestion Products of incomplete oxidation of fatty acids of food

Invades dhatus (tissues) and adheres to normal structures

Binds to proteins and produce structural and functional abnormalities, create new antigenic sites [57]

Digested by a strong Agn (digestive fire)

MDA is metabolised by aldoreductase to various products (e.g. acetaldehyde, acetic acid) $[58,59]$; these products may be used as "food" for "hungry" cells during fasting

Table 3: Ama-like characteristics of lipid peroxidation-derived aldehydes. 


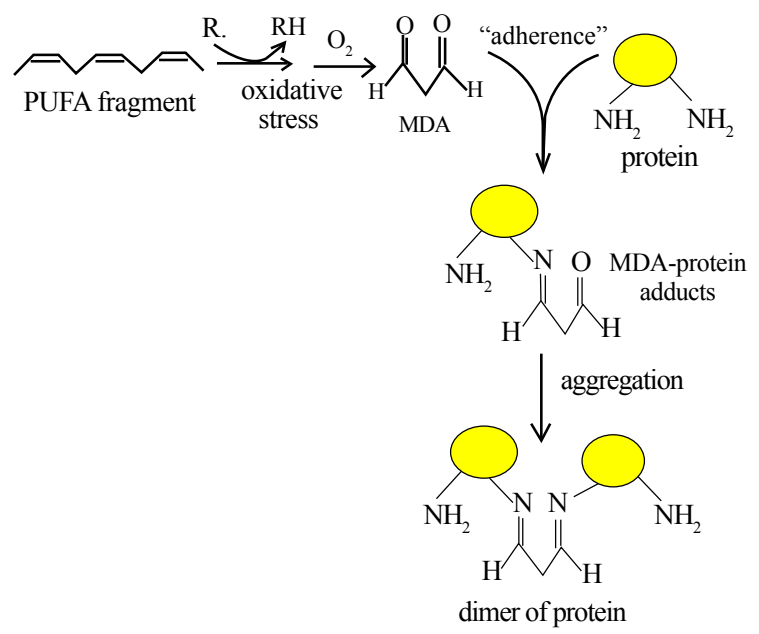

Figure 4: MDA synthesis and its role in the inter-protein crosslinking process.

approaches in managing ageing. While a Rasayana drug has mainly cytoprotective properties, fasting has the capacity to influence free radical production. The both therapies decrease the oxidative damage and induce an increased stress resistance to an oxidative challenge. Fasting could even induce a differential stress resistance (higher in normal cells and lower in cancer cells). In clinical practice, this could lead to many applications, such as the use of much higher doses of chemotherapeutic agents after a pre-fasting treatment [56].

Nevertheless, the main question still remains without answer: Do Rasayana drugs or fasting prolong the life span in human subjects? Although, both approaches can selectively enhance the activity of certain antioxidants, reduce the oxidative damage in various tissues, and enhance longevity in animals, it is not yet systematically studied if they manage to extend life span in humans. Further long term integrative clinical studies are clearly warranted. The integration of modern and traditional concepts is not an easy task, simple equivalences being almost impossible. We have to consider also that the ancient nonquantifiable criteria for quality assessment such as guna (e.g. wet/ snigdha-dry/ruksha, cold/shita-hot/uhna, etc) can not be replaced by simple biochemical or pharmacological measurements. Hence, the integration between ayurveda and modern medicine is possible only to a certain degree at this point, due to the fact that our previous scientific experience is mainly based on the quantitative assessment of different parameters, ignoring almost completely the qualitative aspects, which are primordial in Ayurveda. In order to fill this gap between the two systems, new scientific tools for analyzing the qualities should be developed and also more symbolic scientific thoughts should be framed. Further fundamental scientific studies using animal models and clinical trials in human subjects are required in order to testify the latent therapeutic potential of ayurvedic herbs and therapeutic procedures described in traditional texts in the management of ageing and related disorders.

There is an obvious need to incorporate traditional concepts into the modern medical system in order to "rejuvenate" the framework action research to deliver better clinical antiageing protocols. If correctly understood and approached in scientific manner followed by clinical studies, ayurvedic strategies may represent a "Rasayana pill" for modern medical thought.

\section{References}

1. Beckman KB, Ames BN (1998) The free radical theory of aging matures Physiol Rev 78: 547-581.

2. Samhita C (2005) Text with English translation and critical exposition based on Cakrapani Datta's Ayurveda Dipika, by Sharma RM and Dash B, Chowkhamba Press, Varansi-1, India, Reprint.

3. Anantha Murthy TS (1972) Biography of Shreeman Tapaswiji Mahara (2ndedn) Electron Printers, Bangalore.

4. Gilca M, Stoian I, Atanasiu V, Virgolici B (2007) The oxidative hypothesis of senescence. J Postgrad Med 53: 207-213.

5. Ashtanga Samgraha (2005) translated by KR Srikantha Murthy, Jaikrishnadas Ayurveda Series 79 (5thedn) Varanasi: Chaukhambha Orientalia.

6. Singh RH, Narsimhamurthy K, Singh G (2008) Neuronutrient impact of Ayurvedic Rasayana therapy in brain aging. Biogerontology 9: 369-374.

7. Lee CY, Peng WH, Cheng HY, Chen FN, Lai MT, et al. (2006) Hepatoprotective effect of Phyllanthus in Taiwan on acute liver damage induced by carbon tetrachloride. Am J Chin Med 34: 471-482.

8. Chen TS, Liou SY, Chang YL (2009) Supplementation of Emblica officinalis (Amla) extract reduces oxidative stress in uremic patients. Am J Chin Med 37: $19-25$.

9. Al-Rehaily AJ, Al-Howiriny TA, Al-Sohaibani MO, Rafatullah S (2002) Gastroprotective effects of 'Amla' Emblica officinalis on in vivo test models in rats. Phytomedicine 9: 515-522.

10. Thorat SP, Rege NN, Naik AS, Thatte UM, Joshi A, et al. (1995) Emblica officinalis: a novel therapy for acute pancreatitis--an experimental study. HPB Surg 9: 25-30.

11. Ahmad MK, Mahdi AA, Shukla KK, Islam N, Rajender S, et al. (2010) Withania somnifera improves semen quality by regulating reproductive hormone levels and oxidative stress in seminal plasma of infertile males. Fertil Steril 94: 989996.

12. Bhattacharya SK, Muruganandam AV (2003) Adaptogenic activity of Withania somnifera: an experimental study using a rat model of chronic stress. Pharmacol Biochem Behav 75: 547-555.

13. Rajasankar S, Manivasagam T, Surendran S (2009) Ashwagandha leaf extract: a potential agent in treating oxidative damage and physiological abnormalities seen in a mouse model of Parkinson's disease. Neurosci Lett 454: 11-15.

14. Manikandan S, Srikumar R, Jeya Parthasarathy N, Sheela Devi R (2005) Protective effect of Acorus calamus LINN on free radical scavengers and lipid peroxidation in discrete regions of brain against noise stress exposed rat. Bio Pharm Bull 28: 2327-2330.

15. Shukla PK, Khanna VK, Ali MM, Maurya RR, Handa SS, et al. (2002) Protective effect of acorus calamus against acrylamide induced neurotoxicity. Phytother Res 16: 256-260.

16. Prasad L, Khan TH, Jahangir T, Sultana S (2006) Acorus calamus extracts and nickel chloride: prevention of oxidative damage and hyperproliferation response in rat kidney. Biol Trace Elem Res 113: 77-92.

17. Sairam K, Rao CV, Goel RK (2001) Effect of Centella asiatica Linn on physical and chemical factors induced gastric ulceration and secretion in rats. Indian $\mathrm{J}$ Exp Biol 39: 137-142.

18. Haleagrahara N, Ponnusamy K (2010) Neuroprotective effect of Centella asiatica extract (CAE) on experimentally induced parkinsonism in aged Sprague-Dawley rats. J Toxicol Sci 35: 41-47.

19. Sairam K, Priyambada S, Aryya NC, Goel RK (2003) Gastroduodenal ulcer protective activity of Asparagus racemosus: an experimental, biochemical and histological study. J Ethnopharmacol 86: 1-10.

20. Visavadiya NP, Narasimhacharya AV (2009) Asparagus root regulates cholesterol metabolism and improves antioxidant status in hypercholesteremic rats. Evid Based Complement Alternat Med 6: 219-226.

21. Adhvaryu MR, Reddy N, Parabia MH (2007) Effects of four Indian medicina herbs on Isoniazid-, Rifampicin- and Pyrazinamide-induced hepatic injury and immunosuppression in guinea pigs. World J Gastroenterol 13: 3199-3205.

22. Singh RP, Banerjee S, Kumar PV, Raveesha KA, Rao AR (2006) Tinospora 
cordifolia induces enzymes of carcinogen/drug metabolism and antioxidant system, and inhibits lipid peroxidation in mice. Phytomedicine 13: 74-84.

23. Rawal A, Muddeshwar M, Biswas S (2004) Effect of Rubia cordifolia, Fagonia cretica linn, and Tinospora cordifolia on free radical generation and lipid peroxidation during oxygen-glucose deprivation in rat hippocampal slices. Biochem Biophys Res Commun 324: 588-596.

24. Habbu PV, Shastry RA, Mahadevan KM, Joshi H, Das SK (2008) Hepatoprotective and antioxidant effects of Argyreia speciosa in rats. Afr $J$ Tradit Complement Altern Med 5: 158-164.

25. Joseph CD, Praveenkumar V, Kuttan G, Kuttan R (1999) Myeloprotective effect of a non-toxic indigenous preparation Rasayana in cancer patients receiving chemotherapy and radiation therapy. A pilot study. J Exp Clin Cancer Res 18: 325-329.

26. Ramnath V, Rekha PS, Sujatha KS (2008) Amelioration of heat stress induced disturbances of antioxidant defense system in chicken by brahma rasayana. Evid Based Complement Alternat Med 5: 77-84.

27. Jagetia GC, Malagi KJ, Baliga MS, Venkatesh P, Veruva RR (2004) Triphala, an ayurvedic rasayana drug, protects mice against radiation-induced lethality by free-radical scavenging. J Altern Complement Med 10: 971-978.

28. Nariya M, Shukla V, Jain S, Ravishankar B (2009) Comparison of enteroprotective efficacy of triphala formulations (Indian Herbal Drug) on methotrexate-induced small intestinal damage in rats. Phytother Res 23 1092-1098.

29. Vohra BP, James TJ, Sharma SP, Kansal VK, Chudhary A, et al. (2002) Dark neurons in the ageing cerebellum: their mode of formation and effect of Maharishi Amrit Kalash. Biogerontology 3: 347-354.

30. Pathania V, Syal N, Hundal MK, Khanduja KL (1998) Geriforte stimulates antioxidant defense system. Indian J Exp Biol 36: 414-417.

31. Jagetia GC, Baliga MS (2004) Evaluation of the radioprotective action of geriforte in mice exposed to different doses of gamma-radiation. Am J Chin Med 32: 551-567.

32. Gilca M, Stoian I, Lixandru D, Gaman L, Virgolici B, et al. (2009) Protection of erythrocyte membrane against oxidative damage by geriforte in healthy human subjects. Rom J Intern Med 47: 289-295

33. Bansal A, Sairam M, Prasad D, Sharma SK, llavazhagan G, et al. (2001) Cytoprotective and immunomodulatory properties of Geriforte, a herbomineral preparation, in lymphocytes. Phytomedicine 8: 438-444.

34. Thippeswamy T, McKay JS, Quinn JP, Morris R (2006) Nitric oxide, a biological double-faced janus--is this good or bad? Histol Histopathol 21: 445-458.

35. Valko M, Leibfritz D, Moncol J, Cronin MT, Mazur M, et al. (2007) Free radicals and antioxidants in normal physiological functions and human disease. Int $\mathrm{J}$ Biochem Cell Biol 39: 44-84.

36. Oliveira BF, Nogueira-Machado JA, Chaves MM (2010) The role of oxidative stress in the aging process. ScientificWorldJournal 10: 1121-1128.

37. Powers SK, Jackson MJ (2008) Exercise-induced oxidative stress: cellular mechanisms and impact on muscle force production. Physiol Rev 88: 12431276

38. Vladimirov YA, Proskurnina EV, Izmailov DY (2007) Chemiluminescence as a method for detection and study of free radicals in biological systems. Bull Exp Biol Med 144: 390-396.

39. Decoursey TE, Ligeti E (2005) Regulation and termination of NADPH oxidase activity. Cell Mol Life Sci 62: 2173-2193.

40. Azad N, lyer A, Vallyathan V, Wang L, Castranova V, et al. (2010) Role of oxidative/nitrosative stress-mediated $\mathrm{Bcl}-2$ regulation in apoptosis and malignant transformation. Ann N Y Acad Sci 1203: 1-6.

41. Han D, Ybanez MD, Ahmadi S, Yeh K, Kaplowitz N (2009) Redox regulation of tumor necrosis factor signaling. Antioxid Redox Signal 11: 2245-2263.

42. Ramasarma $\mathrm{T}(1990) \mathrm{H} 2 \mathrm{O} 2$ has a role in cellular regulation. Indian J Biochem Biophys 27: 269-274.

43. Descamps O, Riondel J, Ducros V, Roussel AM (2005) Mitochondrial production of reactive oxygen species and incidence of age-associated lymphoma in OF1 mice: effect of alternate-day fasting. Mech Ageing Dev 126 1185-1191.
44. Barja G (2004) Aging in vertebrates, and the effect of caloric restriction: mitochondrial free radical production-DNA damage mechanism? Biol Rev Camb Philos Soc 79: 235-251.

45. Gilca M, Chirila M, Dinu V (2003) Effect of fasting (80h) on the luminolenhanced chemiluminescence of the polymorphonuclear leukocytes in healthy human subjects. Rom J Intern Med 41: 75-81.

46. Masoro EJ, Austad SN (1996) The evolution of the antiaging action of dietary restriction: a hypothesis. J Gerontol A Biol Sci Med Sci 51: B387-391.

47. Raji NS, Surekha A, Rao KS (1998) Improved DNA-repair parameters in PHAstimulated peripheral blood lymphocytes of human subjects with low body mass index. Mech Ageing Dev 104: 133-148.

48. Anson RM, Guo Z, de Cabo R, Iyun T, Rios M, et al. (2003) Intermittent fasting dissociates beneficial effects of dietary restriction on glucose metabolism and neuronal resistance to injury from calorie intake. Proc Natl Acad Sci U S A 100: 6216-6220.

49. Sogawa $H$, Kubo $C(2000)$ Influence of short-term repeated fasting on the longevity of female (NZB x NZW)F1 mice. Mech Ageing Dev 115: 61-71.

50. Minois N (2000) Longevity and aging: beneficial effects of exposure to mild stress. Biogerontology 1: 15-29.

51. Calabrese V, Guagliano E, Sapienza M, Panebianco M, Calafato S, et al. (2007) Redox regulation of cellular stress response in aging and neurodegenerative disorders: role of vitagenes. Neurochem Res 32: 757-773.

52. Liu D, Chan SL, de Souza-Pinto NC, Slevin JR, Wersto RP, et al. (2006) Mitochondrial UCP4 mediates an adaptive shift in energy metabolism and increases the resistance of neurons to metabolic and oxidative stress. Neuromolecular Med 8: 389-414.

53. Lee KH, Bartsch H, Nair J, Yoo DH, Hong YC, et al. (2006) Effect of shortterm fasting on urinary excretion of primary lipid peroxidation products and on markers of oxidative DNA damage in healthy women. Carcinogenesis 27 : 1398-1403.

54. Castello L, Froio T, Maina M, Cavallini G, Biasi F, et al. (2010) Alternate-day fasting protects the rat heart against age-induced inflammation and fibrosis by inhibiting oxidative damage and NF-kB activation. Free Radic Biol Med 48: 47-54.

55. Castello L, Froio T, Cavallini G, Biasi F, Sapino A, et al. (2005) Calorie restriction protects against age-related rat aorta sclerosis. FASEB J 19: 18631865

56. Johnson JB, John S, Laub DR (2009) Pretreatment with alternate day modified fast will permit higher dose and frequency of cancer chemotherapy and better cure rates. Med Hypotheses 72: 381-382

57. Requena JR, Fu MX, Ahmed MU, Jenkins AJ, Lyons TJ, et al. (1996) Lipoxidation products as biomarkers of oxidative damage to proteins during lipid peroxidation reactions. Nephrol Dial Transplant 11 Suppl 5: 48-53.

58. Siu GM, Draper HH (1982) Metabolism of malonaldehyde in vivo and in vitro. Lipids 17: 349-355.

59. Esterbauer H, Schaur RJ, Zollner H (1991) Chemistry and biochemistry of 4-hydroxynonenal, malonaldehyde and related aldehydes. Free Radic Bio Med 11: 81-128. 